\title{
Nominal Effects of Changes in Total Factor Productivity: Evidence for an Emerging Economy
}

\author{
Leonardo Bianchi dos Santos ${ }^{1} \&$ Ricardo Ramalhete Moreira ${ }^{1}$ \\ ${ }^{1}$ Federal University of Espírito Santo, Brazil \\ Correspondence: Ricardo Ramalhete Moreira, Federal University of Espírito Santo, Brazil. CNPq's Researcher. \\ E-mail: ricardo.moreira@ufes.br
}

Received: October 8, 2019

Accepted: October 30, 2020

Online Published: November 25, 2020

doi:10.5539/ijef.v12n12p89

URL: https://doi.org/10.5539/ijef.v12n12p89

\begin{abstract}
Although there is a considerable amount of literature on applied Phillips Curves and Total Factor Productivity (TFP) for Brazil, the related works have not empirically addressed the effects of the latter on consumer inflation. Thus, our work provided evidence to bridge this gap. Through estimates from different New Keynesian Phillips Curves, and including TFP measures, we found robust impacts of productivity gains on the inflation rate of the Brazilian economy, suggesting an improvement of the trade-off between inflation and unemployment. Furthermore, we found strong evidence indicating that unemployment rate deviations are a better proxy for economic activity, when compared with output gaps, as a way to estimate New Keynesian Phillips curves.
\end{abstract}

Keywords: total factor productivity, inflation, New Keynesian Phillips Curve, Brazil

JEL: E3; E5; O4.

\section{Introduction}

Empirical studies on productivity growth impacts are generally associated with long-term analysis and economic growth (Krugman, 1994; Bonelli \& Fonseca, 1998; Hulten, 2001; Ferreira et al., 2008, 2013; Ellery Jr., 2014). Few works have addressed the effects of productivity growth on the inflation rate in the short run. Some of the few examples in the recent international literature are Ball and Moffitt (2001), Dew-Becker and Gordon (2005), Ambrocio and Jang (2009), Galvin et al. (2012) and more recently Mewael \& Tesfaselassie (2018). However, these works generally use a labor productivity meaurement rather than total factor productivity (TFP), the latter being more wide-ranging than the former for estimating effects on inflation.

In the Brazilian case in particular, although there is extensive literature on factors associated with the inflation rate (generally using Phillips Curve estimates for the country), such as Schwartzman (2006), Areosa and Medeiros (2007) and Mendonça et al. (2012), there are no works that test for the effects of TFP on the fluctuations of the inflation rate. Even the most recent empirical literature, already incorporating the theoretical advances of the New Keynesian Phillips Curve (NKPC), does not contain any productivity measurement as a regressor in the estimated equations.

Therefore, the main contribution of this article is to provide pioneer empirical evidence that bridges this gap in the literature for the case of Brazil. We will make estimates for the NKPC from January 2003 to December 2015 as a means of conducting an empirical investigation of the relationship between TFP variation and inflation in the short term. Three measurements of TFP variation will be used by calculating a Cobb-Douglas Hicks Neutral function, based on the decomposition of productivity growth adopted by Barbosa Filho and Pessoa (2014). To estimate the regressions, the Generalized Method of Moments (GMM) was used, given the need to control regressor endogeneity. The results point to the robust confirmation of the theoretical hypothesis that total factor productivity gains are associated with benign (inverse) effects on the country's inflation rate.

The article is organized as follows. In the following section, we give a brief explanation of the theoretical aspects regarding (New Keynesian) Phillips Curves and Total Factor Productivity. Section 3 presents the data used for estimation purposes, the TFP indices and the methodological strategy. The fourth section analyzes the results of the regressions estimated using GMM. The article ends with concluding remarks, followed by the references and endnotes. 


\section{Theoretical Aspects: New Keynesian Phillips Curve and Productivity}

To investigate the apparent overestimation of inflation rates using the Phillips Curve for the American economy in the 1990s, Ball and Moffitt (2001) proposed a model based on the following idea: workers' aspirations for wage increases adjust slowly to shifts in productivity growth. As a result of differing productivity and wage growth, a shift in the Phillips Curve would take place.

The strong correlation between real wages and productivity in the long run is widely known and incontestable (Ball \& Moffitt, 2001). However, a change in productivity growth does not immediately alter workers' wage aspirations in the short run and vice versa. To these authors, wage aspirations partly depend on past wage growth.

To test whether the differential between productivity and real wages affects inflation, the authors proposed a variation of the traditional Phillips Curve. The real gains desired by workers were defined as a function of the level of employment, productivity and exogenous wage increase aspirations, which in turn is a function of past wage growth.

Therefore, in the model proposed by the authors, the Ball-Moffitt Phillips Curve (BMPC) is composed of past inflation, the unemployment rate and the difference between productivity gains and autonomous real wage increase aspirations, weighted by a parameter that measures how much productivity growth is transferred to wages. So, this is a traditional Phillips Curve with an added variation of productivity not absorbed by real wages. As for the empirical results, Ball and Moffitt (2001) found estimates showing that whereas for 1962-1995 the traditional Phillips Curve explained the inflation rate for the American economy reasonably well, this did not occur for the post-1996 period, for which the traditional Phillips Curve overestimated the inflation rate in relation to actual inflation.

In turn, when the authors estimated the BMPC, with the component that captures the differential between productivity and real wages, the overestimated inflation rate was eliminated for the post-1996 period, as the model began to control for the negative effect on inflation by the component of the differential in this sub-period of the sample.

Clarida, Galí, and Gertler (1999), however, developed a New Keynesian Phillips Curve (NKPC) derived from explicit individual optimizing decisions of firms in an environment of monopolistic competition. Based on the problem of maximizing firms' profits, the authors postulated that short-term price rigidity stems from the fact that firms do not continually adjust prices. Thus, some firms reset prices to maximize profit based on the projection of their future marginal costs, while others maintain their prices for a determined time. Therefore, the NKPC is made up of inflation expectations, the output gap and an error term representing a supply shock.

It is necessary to discuss another two derivations of the New Keynesian Phillips Curve (NKPC): The Hybrid New Keynesian Phillips Curve (HbNKPC) and the Galí and Monacelli New Keynesian Phillips Curve (GMNKPC). While the former model includes the backward-looking component of inflation in the NKPC equation, the latter model is developed for a small open economy, with a component for the variation of exchange terms with the rest of the world.

Developed by Galí and Gertler (1999), the HbNKPC is based on the same premises as the conventional NKPC. However, it is assumed that a fraction of the firms reset their prices based on past inflation rather than the optimal price estimated based on the projection of marginal future cost. Another change is the substitution of the output gap by the real marginal cost deviation as a proxy for the component that represents the real activity of the economy. Thus, the HbNKPC is made up of past inflation, inflation expectations, marginal cost deviation and an error term representing a supply shock.

The GMNKPC, developed by Galí and Monacelli (2005), is based on the assumption that the variations of exchange terms affects inflation rates in open economies. The authors included in the original equation a component that captures the variation of exchange terms, weighted by the degree of openness of the economy. The lower the degree of openness of the economy, the lower the impact of the variation of exchange terms will be on current inflation. If the parameter of openness is zero, it is necessary to return to the original equation of the NKPC. Thus, the GMNKPC is composed of inflation expectation, the real marginal cost deviation and the variation of exchange terms weighted by the degree of openness of the economy.

An example in the international literature that estimated the effects of productivity on the inflation rate using the New Keynesian Phillips Curve (NKPC) and the hybrid (HbNKPC) was Ambrocio and Jang (2009). According to these authors, the study was motivated by the bad fit of the models of the New Keynesian Phillips Curve to the most recent data on the American economy and the Eurozone, making it necessary to return to using structures 
incorporating supply-side inflationary pressures and rigidities that may affect the wage adjustment process. Following Gali and Gertler (1999), the authors derived their New Keynesian Phillips Curve with some modifications on the supply side to emphasize the effects of productivity shocks on the inflation rate. The demand side was formed by a utility function in which consumers maximize their well-being. The supply side, in turn, was resolved by a maximizing function in which the firm producing output $j$ maximizes its profit in monopolistic competition.

Based on the treatment of productivity by Ball and Moffitt (2001), Ambrocio and Jang (2009) included productivity growth in the Hybrid New Keynesian Phillips Curve as a conduit to the inflation. It should be highlighted that Ball and Moffitt (2001) treated productivity as a supply shock. Thus, the model proposed by Ambrocio and Jang (AJNKPC) is composed of backward-looking and forward-looking components of inflation through changes in the marginal cost deviations in relation to their trend values and rising labor productivity. The findings of these authors are in keeping with the predictions of the model. The coefficient linked to productivity growth, $\xi$, yielded the expected sign (negative) and with statistical significance for the American economy, although not for the Eurozone data.

It is important to highlight that the productivity measurement used by Ball and Moffitt (2001) and Ambrocio and Jang (2009) refers only to labor productivity. Although there are some advantages to using labor productivity, such as the ease of constructing a time series, it is only a partial measurement. Some problems are intrinsic to this partial productivity measurement, such as not identifying changes between the isoquants of the production factors. The use of a Total Factor Productivity (TFP) measurement is better suited, given that it controls the variations of productivity stemming from the dimension of capital stock over time.

Mewael and Tesfaselassie (2018), in turn, adopted a simple two-sector framework based on price staggering as well as labor market frictions. Such a model was augmented to allow for productivity growth, so that productivity growth was reflected in all existing and newly employed workers. Using data from the US and four largest European economies, Mewael \& Tesfaselassie (2018) found evidence of non-linearity of the response of inflation rates to productivity growth, depending on the behavior of unemployment trend over time. In regimes of low inflation, an increasing productivity growth was accompanied by higher levels of unemployment trend; in contrast, an increasing productivity growth was followed by lower unemployment levels in regimes of high inflation rates. Relationships between productivity growth and unemployment are also a correlated and relevant issue. In general, there is no consensus on its precise signal.

For instance, Gallegati et al. (2016) analyzed empirical relationships between productivity and unemployment from different time designs through wavelet analysis. The scale-by-scale findings from panel data and nonparametric regressions suggested that productivity-unemployment relationship is scale-dependent, thereby varying over different time horizons. Particularly, productivity growth created unemployment in the short and medium terms, but employment in the long-run. However, our current study is mainly interested in identifying effects of total factor productivity on inflation rates for a given level of unemployment rate (or output gap).

Finally, Snower and Tesfaselassie (2017) calibrated a New Keynesian model for the US with parameters within a range of values usually used in the literature. The main result was that job turnover and trend productivity growth flatten the long-run Phillips curve, that is, an increase in trend inflation was associated with a larger percentage increase in steady state employment and consumption.

Based on these issues, our study estimated the potential effects of changes in TFP on inflation in the Brazilian economy, using the following general form of a New Keynesian Phillips Curve:

$$
\pi_{t}=a+\lambda x_{t-n}+\gamma_{b} \pi_{t-n}+\gamma_{f} E_{t}\left\{\pi_{t+12}\right\}+\phi\left[\Delta q_{t-n}\right]+\xi \Delta t f p_{t-n}+v_{t}
$$

Where $\pi_{t}$ stands for inflation rate in the current period, $a$ is an exogenous constant, $x_{t-n}$ is the output gap (or, alternatively in some specifications, the unemployment rate gap) in period $t-n$, with $n$ being an effective empirically identified lag horizon; $E_{t}\left(\pi_{t+12}\right)$ represents accumulated inflation expectations for the next 12 months, $\Delta q_{t-n}$ is the variation of the nominal exchange rate, $\Delta t f p_{t-n}$ is the variation of Total Factor Productivity (TFP) and $v_{t}$ is an error term. While positive estimated values are expected for $\gamma_{b}, \gamma_{f}$ and $\phi$, a negative estimated value is expected for $\xi$. In the case of $\lambda$, the expected value is positive when accompanied by the output gap, but negative if accompanied by $x_{t}$ as the unemployment rate gap.

\section{Data, TFP Indices and Methodological Strategy}

\subsection{Data and TFP Indices}

The sample period of the series is from January 2003 to December 2015, mainly due to the limited availability of data for many of the series used in the study. The larger number of observations notwithstanding, monthly data 
are subject to greater noise and errors of measurement, especially in data interpolation. Furthermore, as pointed out by Schwartzman (2006), there is a greater risk of autocorrelation of data, which requires greater care in the econometric estimations and in fitting the lags in the tested models.

The index chosen for inflation, the dependent variable of the models to be estimated, was the monthly IPCA, official inflation rate in Brazil calculated by the Brazilian Institute of Geography and Statistics (IBGE). The monthly variation series of the index was obtained from the IPEADATA platform (Note 1). The series of the average expectation of the accumulated inflation rate for the next twelve months (Note 2) was also obtained from the IPEA website. The use of effectively observed inflation expectations in the regressions reduces the possibility of inaccuracies, as in the eventual use of a series of estimated inflation expectations.

For the component that reflects economic activity in the Phillips Curve, two indicators were chosen: the deviation of the seasonally adjusted Brazilian Central Bank Economic Activity Index (IBC-Br), expressing the output gap, and the deviations of the opened unemployment rate in São Paulo (Note 3), as a proxy of the marginal cost deviations. The deviations in relation to the series trends were calculated using the Hodrick-Prescott (HP) filter. The two series were obtained from the IPEADATA platform.

In turn, to estimate the exchange pass-through effect on inflation, the series of the nominal exchange rate variation (Note 4) was obtained from the exchange rate series for the sale of American dollars at the end of each period. The Need for Nominal Financing of the Public Sector (NFPS) series, in relation to GDP, was used to analyze any influence of fiscal policy on price variations, while the Selic rate (i.e. Brazil's basic nominal interest rate) accumulated over twelve months was used as an instrument in the GMM estimations. Both the nominal exchange rate and the NFPS series were taken from the time series generation system (TSGS) of the Central Bank. The Selic rate series was obtained from the IPEADATA platform.

Finally, three TFP series were built on growth accounting methodology to analyze the influence of productivity variation on the inflation rate. For this purpose, the series of the deflated monthly GDP of the Central Bank was used, as well as the economically active population (EAP) of the PNAD (National Residential Sampling Research) (Note 5), the use of productive capacity provided by the National Confederation of Industry (NCI), non-residential electricity consumption and the opened unemployment rate for São Paulo state. All the aforementioned series can be obtained from the IPEADATA digital platform.

To obtain the productivity variation series, output growth was decomposed following the procedure adopted by Barbosa Filho and Pessoa (2014). From a Cobb-Douglas Hicks-Neutral function, productivity variation in period $t$ is equal to:

$$
\ln \left(\frac{A_{t+1}}{A_{t}}\right)=\ln \left(\frac{Y_{t+1}}{Y_{t}}\right)-\alpha \ln \left(\frac{K_{t+1}}{K_{t}}\right)-(1-\alpha) \ln \left(\frac{L_{t+1}}{L_{t}}\right)
$$

Where productivity variation $\left(\frac{A_{t+1}}{A_{t}}\right)$ is equal to output variation $\left(\frac{Y_{t+1}}{Y_{t}}\right)$ minus capital variation $\left(\frac{K_{t+1}}{K_{t}}\right)$ and labor variation $\left(\frac{L_{t+1}}{L_{t}}\right)$, weighted by their respective shares of total income, i.e., $\alpha$ and $(1-\alpha)$.

The capital stock series, also used to construct the TFP series, was calculated based on the perpetual inventory methodology (Note 6). However, it was necessary to obtain the value of the initial capital stock for the series, as well as the capital depreciation rate and investment during the period. Again in accordance with Barbosa Filho and Pessoa (2014), and based on the work of Gomes, Pessoa and Veloso (2003), the capital-output relationship of December of 1996, equal to 2.4793 (Note 7) was assumed, in addition to a capital depreciation rate of 3.5\% and the value of the share of capital in income of $40 \%(\alpha=0.4)$. The value of the investment of each period was determined from a quarterly variation series of the gross formation of fixed capital with an exponential interpolation between the quarters to fill in the monthly data.

Thus, the base model of the TFP variation series (TFPBASE) was obtained from the monthly GDP series $(P I B m)$, the capital stock $(E s t K)$ and the economically active population $(E A P)$ series of the PNAD. In the second conceived TFP series (TFPADJUST), capital stock was adjusted by the use of used capacity of industry $(C I)$, while the EAP series was corrected by the opened unemployment rate in São Paulo (USP). Finally, in the last series of the TFP variation (TFPALTER), non-residential electric energy consumption $(E E)$ was used as a proxy for capital stock, while the employed people series of the monthly unemployment figures $(P O C)$ replaced the EAP series.

The use of the three measurements for TFP was intended to replicate the different approaches for measuring TFP 
in the empirical literature. The justification for using the base TFP model (TFPBASE) is to capture the variation of the productivity of the factors based on the availability of these production factors for a given variation of the output. In turn, the adjusted model of the TFP variation (TFPADJUST) captures the variation in productivity by the effective use of production factors for a given variation of the output. Finally, the use of the alternative model (TFPALTER) is justified by the replacement of the controversial and difficult to measure stock capital (EstK) variable by the measurement of non-residential electricity consumption $(E E)$, which captures the effective use of capital at a given time. The alternative TFP measurement also uses the Employed People series $(P O c)$, which can be understood as a more adequate measurement for measuring the labor factor than EAP. Table 1 shows the series used in the regressions, their description and respective data sources.

Table 1. Variables used

\begin{tabular}{|c|c|c|c|}
\hline Acronym & Variable & Description & Data Source \\
\hline IPCA & Price Index & Monthly variation of the Extended National Consumer Price Index (IPCA) & ATA \\
\hline EIPCA & Inflation Expectation & verage expectations of the market for following 12 months (last working day) & IPEADATA \\
\hline DEV_IBC & Economic Activity & Deviations of the IBC-Br activity index (calculated using HP Filter) & IPEADATA \\
\hline DEV_U & Economic Activity & Deviations of open unemployment rate in SP (calculated using HP Filter) & IPEADATA \\
\hline $\mathrm{EXCH}$ & Nominal Exchange & $\begin{array}{l}\text { Monthly variation of American dollar exchange rate (purchase) - last working } \\
\text { day }\end{array}$ & SGS/BACEN \\
\hline NFPS & Nominal Fiscal Result & Need for nominal financing of the public Sector in relation to GDP & CEN \\
\hline SELIC & Annualized Selic Rate & Annualized Selic Rate in the mont & SGS/BACEN \\
\hline TFPBASE & Base TFP Model & $\ln \left(\frac{P I B m_{t+1}}{P I B m_{t}}\right)-0,4 \ln \left(\frac{E s t K_{t+1}}{E s t K_{t}}\right)-0,6 \ln \left(\frac{P E A_{t+1}}{P E A_{t}}\right)$ & Own Estimation \\
\hline TFPADJUST & Adjusted TFP Model & $\ln \left(\frac{P I B m_{t+1}}{\text { PIBm }_{t}}\right)-0,4 \ln \left(\frac{C I_{t+1} E s t K_{t+1}}{C I_{t} E s t K_{t}}\right)-0,6 \ln \left(\frac{D S P_{t+1} P E A_{t+1}}{D S P_{t} P E A_{t}}\right)$ & Own Estimation \\
\hline TFPALTER & Alternative TFP Model & $\ln \left(\frac{P I B m_{t+1}}{P I B m_{t}}\right)-0,4 \ln \left(\frac{E E_{t+1}}{E E_{t}}\right)-0,6 \ln \left(\frac{P O c_{t+1}}{P O c_{t}}\right)$ & Own Estimation \\
\hline
\end{tabular}

Source: Own elaboration.

Figure 1 shows the behavior of the three total factor productivity indices at the level used in this work. For the sample period, it should be observed that of the three measurements TFPBASE is the one that generally has higher TFP values (and also a higher growth rate), while TFPALTER in most cases has the lowest values for total productivity (and also the lowest growth rates). In turn, TFPADJUST has intermediate values in most of the sample. These differences were expected given that the three indices are constructed from methodological changes. However, in the period as a whole, it is evident that the behavior of the three TFP measurements converges.

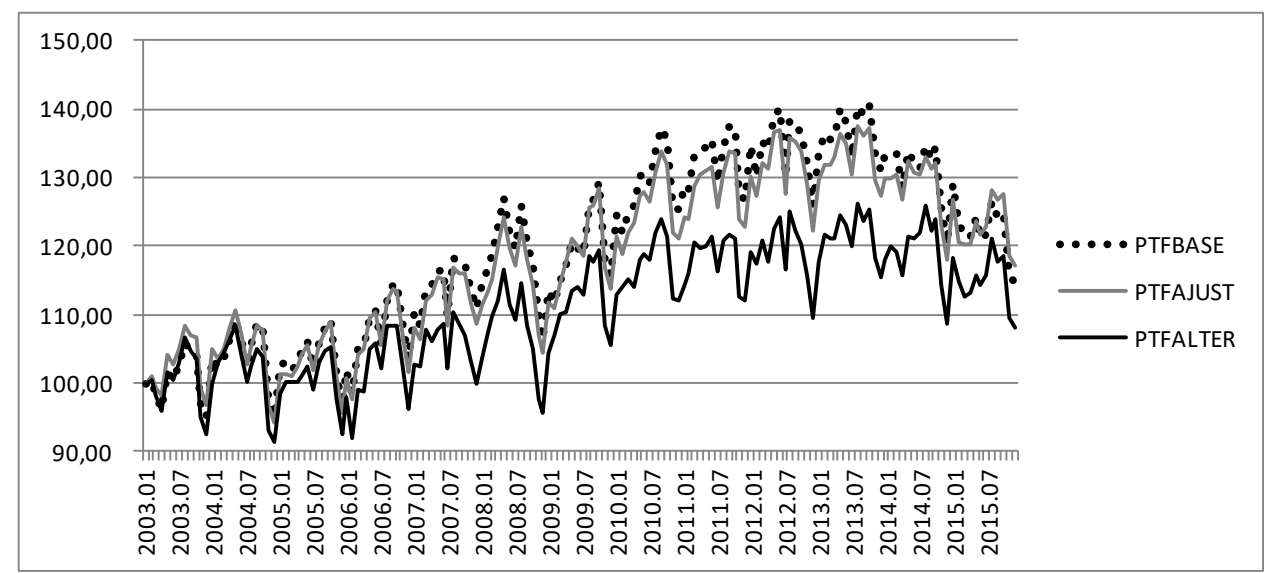

Figure 1. Total Factor Productivity (TFP) indices: TFPBASE, TFPADJUST and TFPALTER (Jan, 2003 to Dec, 2015)

Source: Own elaboration. 


\subsection{Methodological Strategy}

Econometric treatment of time series requires some additional cares to avoid problems in the estimations. Data arranged in the form of time series can often move in the same direction without this implying a relationship of causality between the explanatory and explained variables. Moreover, in the case of a bad specification of the estimated model, spurious correlations can be generated. In other words, to determine a relationship between two variables over time, it must be assumed that there is some stability in the time series. This leads to the need to identify whether a time series is or is not stationary. A time series is stationary if its average and its variance are constant over time and the covariance between the lagged values depends only on the lag between them. In other words, a stationary time series is one whose values constantly fluctuate around the same average.

Thus, the Augmented Dickey-Fuller (ADF) and Phillips-Perron (PP) unit root tests were run to identify whether the series used in the regressions are stationary or not (or with a unit root). In the aforementioned unit root tests, the null hypothesis $\left(\mathrm{H}_{0}\right)$ assumes the presence of the unit root. If the results of the ADF and PP unit root tests diverge, the Kwiatkowski-Phillips-Schmidt-Shin (KPSS) test will be used to test the stationarity of the time series. Unlike the ADF and PP test, the null hypothesis $\left(\mathrm{H}_{0}\right)$ of the KPSS test assumes that the series is stationary.

Table 2 presents the results of the ADF, PP and KPSS tests for all the series used in the estimations of the models. The set of unit root tests rejects the hypothesis of a unit root for all the series used in the estimations, with the exception of the Need for Nominal Financing of the Public Sector (NFPS). Therefore, all the variables of the estimated models will be used in level values, except the NFPS series, which will be used in its first differences.

It is important to emphasize that in the estimated models, inflation can also influence the variables used as regressors. Specifically, inflation expectation in a given period can be influenced by the current inflation of the same period, thus configuring a problem of simultaneity. Therefore, the hypothesis of presence of endogeneity cannot be discarded.

Table 2. Results of the Unit Root Tests

\begin{tabular}{|c|c|c|c|c|c|c|c|}
\hline & $\mathrm{ADF}^{1}$ & $\mathrm{PP}^{2}$ & $\mathrm{KPSS}^{3}$ & $\mathrm{ADF}$ & $\mathrm{PP}^{4}$ & KPSS $^{5}$ & \\
\hline Series & & Level Test & & & rst Difference Te & & $\mathrm{I}(\mathrm{n})$ \\
\hline IPCA & $-7.2763 * * *$ & $-7.2707 * * *$ & 0.2501 & - & - & - & $\mathrm{I}(0)$ \\
\hline EIPCA & $-5.5156 * * *$ & $-6.0760 * * *$ & 0.3406 & - & - & - & $\mathrm{I}(0)$ \\
\hline DEV_IBC & $-4.1019 * * *$ & $-3.2519 * * *$ & 0.0342 & - & - & - & $\mathrm{I}(0)$ \\
\hline DEV_U & $-3.7130 * * *$ & $-4.6125^{* * *}$ & 0.0259 & - & - & - & $\mathrm{I}(0)$ \\
\hline $\mathrm{EXCH}$ & $-12.2582 * * *$ & $-12.2580 * * *$ & 0.0462 & - & - & - & $\mathrm{I}(0)$ \\
\hline SELIC & $-3.4748 * * *$ & $-2.7093 * *$ & $0.2636^{* * *}$ & & & & $\mathrm{I}(0)$ \\
\hline NFPS & 0.8794 & $-11.2442 * * *$ & $0.3069^{* * *}$ & $-7.5251 * * *$ & $-37.9022 * * *$ & $0.4138^{*}$ & $\mathrm{I}(1)$ \\
\hline TFPBASE & $-3.2358 *$ & $-17.9454 * * *$ & 0.3041 & - & - & - & $\mathrm{I}(0)$ \\
\hline TFPADJUST & $-2.92678 * * *$ & $-19.3066 * * *$ & 0.242215 & - & - & - & $\mathrm{I}(0)$ \\
\hline TFPALTER & $-4.07706^{* * *}$ & $-17.8897 * * *$ & $0.441038^{*}$ & - & - & - & $\mathrm{I}(0)$ \\
\hline
\end{tabular}

Obs.: (*) significant at $10 \%,(* *)$ at $5 \%$ and $(* * *)$ at $1 \%$. The significance level for the constant and the trend can vary from 1 to $10 \%$.

Obs.: (1) For the DEV_U and TFPADJUST series, the tests are significant without the trend and without the constant; for the SELIC and TFPALTER series, the tests are significant only with the constant. (2) For the DEV_IBC, DEV_U, TFPBASE, TFPADJUST and TFPALTER series, the tests are significant without the trend and without the constant; for the SELIC series, the test is significant only with the constant. (3) For the DEV_IBC, DEV_U, TFPBASE, TFPADJUST and TFPALTER series, the tests are significant without the trend and without the constant; for the IPCA and EIPCA series, the tests are significant only with the constant. (4)(5) For the NFPS series, the tests is significant without the constant and without the trend.

Source: Own elaboration.

With this possibility in mind, the use of the Generalized Method of Moments (GMM) is a good solution. In brief, the GMM relaxes the hypothesis of non-correlation of the regressors with the error term using exogenous instrumental variables that are correlated with the regressors. The GMM estimator is minimized by weighting each condition of independence between the instrumental variables and the error term, with the moment conditions with greater variance receiving less weight (Hansen, 1982). Thus, the use of the GMM is an option for excluding unobserved effects in the estimations, with a consistent and efficient estimator even with omitted variables in the model and simultaneity (Cragg, 1983). 
Finally, it is necessary to highlight three further cares that should be taken in estimations by GMM. The first is the number of observations, as the method is not consistent for small samples. The second point to observe is that the number of instruments has to be equal to or greater than the number of estimated regressors. The final point is the condition of exogeneity of the chosen instruments, which can be gauged through the non-rejection of the null hypothesis of the J Test (Johnston, 1984).

\section{Results}

For each productivity index (baseline, adjusted and alternative TFP), a set of eight specifications was estimated, as shown in Tables 3, 4 and 5. The parameters of Base TFP and Adjusted TFP were significant and with the expected sign (negative) in two specifications of the Phillips Curve, particularly with the unemployment deviation as a proxy for economic activity. Regarding Alternative TFP, all the parameters had statistical significance and the expected sign when the unemployment deviation was used as such a proxy, thereby identifying it as presenting a higher power of adherence to data in comparison with our other economic activity proxies.

The statistically significant coefficient values varied between -1.60 and -0.97 , pointing to a strong transfer from the variation of TFP to consumer prices in Brazil. The specifications of the GMNKPC with deviation of unemployment generally had the highest statistically significant coefficients regarding TFP effects on consumer inflation.

Table 3. Phillips Curve with Base TFP (GMM)

\begin{tabular}{|c|c|c|c|c|c|c|c|c|}
\hline Explanatory variable & NKPC & $\mathrm{HbNKPC}$ & GMNKPC & GM NKPC & NKPC & $\mathrm{HbNKPC}$ & GMNKPC & GMNKPC \\
\hline \multirow{3}{*}{$\mathrm{C}$} & -0.1531 & 0.0181 & 0.0641 & 0.0629 & -0.0004 & 0.0628 & 0.1200 & 0.1172 \\
\hline & $(0.1662)$ & $(0.1006)$ & $(0.0978)$ & $(0.1015)$ & $(0.1483)$ & $(0.1253)$ & $(0.1198)$ & $(0.1210)$ \\
\hline & {$[-0.9212]$} & {$[0.1801]$} & {$[0.6561]$} & [0.6204] & {$[-0.0031]$} & {$[0.5015]$} & [1.0015] & [0.9681] \\
\hline \multirow[t]{3}{*}{$\mathrm{IPCA}_{\mathrm{t}-1}$} & & $0.671^{* * *}$ & $0.625 * * *$ & $0.6139 * * *$ & & 0.2782 & 0.2189 & 0.2299 \\
\hline & & $(0.1673)$ & $(0.1461)$ & $(0.1483)$ & & $(0.1903)$ & $(0.1745)$ & $(0.1881)$ \\
\hline & & [4.0135] & [4.2823] & [4.1396] & & [1.4616] & [1.2544] & [1.2221] \\
\hline \multirow[t]{3}{*}{ EIPCA $_{t-1}$} & $0.118^{* * *}$ & 0.0272 & 0.0212 & 0.0226 & $0.0920 * * *$ & $0.0548 *$ & $0.0501 *$ & 0.0493 \\
\hline & $(0.0314)$ & $(0.0244)$ & $(0.0211)$ & $(0.0216)$ & $(0.0275)$ & $(0.0306)$ & $(0.0283)$ & $(0.0301)$ \\
\hline & {$[3.7675]$} & {$[1.1171]$} & [1.0067] & [1.0455] & [3.3353] & [1.7907] & [1.7661] & [1.6407] \\
\hline \multirow[t]{3}{*}{ TFPBASE $_{\mathrm{t}-2}$} & $1.7789^{*}$ & 0.5253 & -0.0144 & 0.1760 & -0.6426 & -0.6299 & $-0.9889^{*}$ & $-1.0874 *$ \\
\hline & $(0.9854)$ & $(0.6658)$ & $(0.7428)$ & $(0.8886)$ & $(0.5291)$ & $(0.4714)$ & $(0.5391)$ & $(0.6387)$ \\
\hline & [1.8052] & [0.7889] & {$[-0.0194]$} & [0.1980] & {$[-1.2145]$} & {$[-1.3363]$} & {$[-1.8343]$} & {$[-1.7025]$} \\
\hline \multirow[t]{3}{*}{ DEV_IBC $C_{t-2}$} & 0.0119 & 0.0001 & -0.0039 & -0.0037 & & & & \\
\hline & $(0.0098)$ & $(0.0070)$ & $(0.0066)$ & $(0.0067)$ & & & & \\
\hline & [1.2184] & {$[0.0175]$} & {$[-0.5966]$} & {$[-0.5474]$} & & & & \\
\hline \multirow[t]{3}{*}{ DEV_U ${ }_{t-2}$} & & & & & $-0.1089 * * *$ & $-0.072 * *$ & $-0.0778^{*}$ & $-0.0741^{*}$ \\
\hline & & & & & $(0.0318)$ & $(0.0335)$ & $(0.0396)$ & $(0.0381)$ \\
\hline & & & & & {$[-3.4180]$} & {$[-2.1724]$} & {$[-1.9631]$} & [-1.9419] \\
\hline \multirow[t]{3}{*}{$\mathrm{EXCH}_{\mathrm{t}-2}$} & & & $1.7107 * *$ & $1.8765^{*}$ & & & 1.3925 & 1.1636 \\
\hline & & & $(0.8620)$ & $(0.9527)$ & & & (0.8992) & $(0.8672)$ \\
\hline & & & [1.9844] & [1.9696] & & & [1.5485] & [1.3416] \\
\hline \multirow[t]{3}{*}{$\mathrm{D}(\mathrm{NFPS})_{\mathrm{t}-1}$} & & & & 0.0022 & & & & -0.0020 \\
\hline & & & & $(0.0061)$ & & & & $(0.0052)$ \\
\hline & & & & [0.3602] & & & & {$[-0.3966]$} \\
\hline Adjusted $\mathrm{R}^{2}$ & 0.0262 & 0.3562 & 0.3868 & 0.3671 & 0.2880 & 0.3976 & 0.3650 & 0.3774 \\
\hline J Statistic & 11.1046 & 8.0726 & 8.2399 & 8.2723 & 11.1123 & 12.3547 & 12.7978 & 12.7892 \\
\hline $\operatorname{Prob}(\mathrm{J})$ & 0.5199 & 0.7067 & 0.8276 & 0.7634 & 0.5193 & 0.3375 & 0.4635 & 0.3845 \\
\hline Instrument Rank & 16 & 16 & 19 & 19 & 16 & 16 & 19 & 19 \\
\hline
\end{tabular}

Obs.: () for standard deviation and [] for t statistic. (*) significant at $10 \%(* *)$ at $5 \% \mathrm{e}(* * *)$ at $1 \%$.

Obs.: Instrumental variables used: EIPCA(t-2, t-3, t-4), SELIC(t-2, t-3, t-4), D(NFPS)(t-2, t-3, t-4), TFPBASE(t-3, t-4, t-5). The EXCH(t-3, $\mathrm{t}-4, \mathrm{t}-5)$, DEV_IBC(t-3, t-4, $t-5)$ and DEV_U(t-3, t-4, t-5) instruments were only used when present in the regressions.

Source: Own elaboration. 
Table 4. Phillips Curve with Adjusted TFP (GMM)

\begin{tabular}{|c|c|c|c|c|c|c|c|c|}
\hline Explanatory variable & NKPC & HbNKPC & GMNKPC & GMNKPC & $\mathrm{HbNKPC}$ & NKPC & GMNKPC & GMNKPC \\
\hline \multirow{3}{*}{$\mathrm{C}$} & -0.1518 & 0.0345 & 0.0784 & 0.0808 & 0.0687 & 0.0141 & 0.1399 & 0.1364 \\
\hline & $(0.1701)$ & (0.0994) & $(0.0954)$ & $(0.0998)$ & $(0.1296)$ & $(0.1488)$ & $(0.1233)$ & $(0.1218)$ \\
\hline & {$[-0.8924]$} & {$[0.3471]$} & [0.8214] & [0.8093] & [0.5307] & [0.0948] & [1.1349] & [1.1200] \\
\hline \multirow[t]{3}{*}{$\mathrm{IPCA}_{\mathrm{t}-1}$} & & $0.7037 * * *$ & $0.6719 * * *$ & $0.6599 * * *$ & 0.2391 & & 0.2024 & 0.2128 \\
\hline & & $(0.1634)$ & $(0.1390)$ & $(0.1406)$ & $(0.1901)$ & & $(0.1759)$ & $(0.1865)$ \\
\hline & & [4.3057] & [4.8317] & [4.6920] & [1.2579] & & [1.1504] & [1.1413] \\
\hline \multirow[t]{3}{*}{ EIPCA $_{t-1}$} & $0.1188^{* * *}$ & 0.0212 & 0.0143 & 0.0149 & $0.0570 *$ & $0.0890 * * *$ & 0.0476 & 0.0471 \\
\hline & $(0.0322)$ & $(0.0246)$ & $(0.0211)$ & $(0.0216)$ & $(0.0318)$ & $(0.0278)$ & $(0.0292)$ & $(0.0303)$ \\
\hline & [3.6814] & {$[0.8633]$} & {$[0.6748]$} & {$[0.6930]$} & {$[1.7896]$} & [3.2006] & [1.6287] & [1.5539] \\
\hline \multirow[t]{3}{*}{ TFPADJUST $_{\mathrm{t}-2}$} & $1.9225^{*}$ & 0.6020 & 0.1000 & 0.3404 & -0.7107 & -0.6940 & $-1.0257 * *$ & $-1.1043^{*}$ \\
\hline & $(1.0870)$ & $(0.7180)$ & $(0.7787)$ & $(0.9595)$ & $(0.4591)$ & $(0.5065)$ & $(0.5010)$ & $(0.6155)$ \\
\hline & {$[1.7685]$} & [0.8383] & [0.1284] & [0.3547] & {$[-1.5478]$} & {$[-1.3702]$} & {$[-2.0472]$} & {$[-1.7939]$} \\
\hline \multirow[t]{3}{*}{ DEV_IBC ${ }_{t-2}$} & 0.0145 & 0.0003 & -0.0042 & -0.0039 & & & & \\
\hline & $(0.0101)$ & $(0.0070)$ & $(0.0066)$ & $(0.0068)$ & & & & \\
\hline & [1.4288] & {$[0.0524]$} & {$[-0.6360]$} & {$[-0.5787]$} & & & & \\
\hline \multirow[t]{3}{*}{ DEV_U $U_{t-2}$} & & & & & $-0.0822 * *$ & $-0.113 * * *$ & $-0.0834 * *$ & $-0.0801 * *$ \\
\hline & & & & & $(0.0337)$ & $(0.0320)$ & $(0.0381)$ & $(0.0385)$ \\
\hline & & & & & {$[-2.4357]$} & {$[-3.527]$} & [-2.1893] & {$[-2.0763]$} \\
\hline \multirow{3}{*}{$\mathrm{EXCH}_{\mathrm{t}-2}$} & & & $1.7642 * *$ & $1.9719^{* *}$ & & & $1.4759^{*}$ & 1.2676 \\
\hline & & & $(0.8616)$ & $(0.9638)$ & & & $(0.8704)$ & $(0.8718)$ \\
\hline & & & [2.0475] & [2.0458] & & & [1.6956] & [1.4538] \\
\hline \multirow{3}{*}{$\mathrm{D}(\mathrm{NFPS})_{\mathrm{t}-1}$} & & & & 0.0026 & & & & -0.0017 \\
\hline & & & & $(0.0063)$ & & & & $(0.0053)$ \\
\hline & & & & [0.4254] & & & & {$[-0.3262]$} \\
\hline Adjusted $\mathrm{R}^{2}$ & 0.0028 & 0.3418 & 0.3773 & 0.3515 & 0.3924 & 0.2927 & 0.3590 & 0.3720 \\
\hline J Statistic & 11.7120 & 8.0109 & 7.8701 & 7.8462 & 12.2010 & 10.8530 & 12.5440 & 12.5600 \\
\hline $\operatorname{Prob}(\mathrm{J})$ & 0.4690 & 0.7123 & 0.8519 & 0.7970 & 0.3486 & 0.5414 & 0.4835 & 0.4017 \\
\hline Instrument Rank & 16 & 16 & 19 & 19 & 16 & 16 & 19 & 19 \\
\hline
\end{tabular}

Obs.: () for standard deviation and [] for t statistic. (*) significant at $10 \%,(* *)$ at $5 \%$ and $(* * *)$ at $1 \%$.

Obs.: Instrumental variables used: EIPCA(t-2, t-3, t-4), SELIC(t-2, t-3, t-4), D(NFPS)(t-2, t-3, t-4), TFPBASE(t-3, t-4, t-5). The EXCH(t-3, $\mathrm{t}-4, \mathrm{t}-5)$, DEV_IBC( $\mathrm{t}-3, \mathrm{t}-4, \mathrm{t}-5)$ and DEV_U $(\mathrm{t}-3, \mathrm{t}-4, \mathrm{t}-5)$ instruments were only used when present in the regressions.

Source: Own elaboration.

In turn, the TFP variables did not respond well to the specifications of the Phillips Curve with the output gap as a proxy for economic activity. Only two regressions brought productivity coefficients with statistical significance in these cases, but with unexpected or a positive sign when IBC-Br deviation was used in the regressions. These results can be interpreted as suggesting that the effects of TFP variation on consumer inflation in Brazil are captured more efficiently when controlling for the unemployment rate deviations, far more than the output deviations.

Table 5. Phillips Curve with Alternative TFP (GMM)

\begin{tabular}{|c|c|c|c|c|c|c|c|c|}
\hline Explanatory variable & NKPC & $\mathrm{HbNKPC}$ & GMNKPC & GMNKPC & NKPC & HbNKPC & GMNKPC & GMNKPC \\
\hline \multirow{3}{*}{$\mathrm{C}$} & -0.1025 & 0.0391 & 0.0792 & 0.0849 & -0.0040 & 0.047 & 0.1066 & 0.1014 \\
\hline & $(0.1520)$ & $(0.0960)$ & $(0.0936)$ & $(0.0977)$ & $(0.1459)$ & $(0.1330)$ & $(0.1239)$ & $(0.1209)$ \\
\hline & {$[-0.6742]$} & [0.4069] & {$[0.8463]$} & {$[0.8691]$} & {$[-0.0278]$} & [0.3579] & {$[0.8604]$} & {$[0.8390]$} \\
\hline \multirow[t]{3}{*}{$\mathrm{IPCA}_{\mathrm{t}-1}$} & & $0.7010 * * *$ & $0.6100^{* * *}$ & $0.6048^{* * *}$ & & 0.200 & 0.1734 & 0.1912 \\
\hline & & $(0.1779)$ & $(0.1516)$ & $(0.1520)$ & & $(0.1858)$ & $(0.1703)$ & $(0.1846)$ \\
\hline & & [3.9402] & [4.0235] & [3.9775] & & {$[1.0765]$} & [1.0181] & {$[1.0357]$} \\
\hline \multirow[t]{3}{*}{ EIPCA $_{t-1}$} & $0.1098 * * *$ & 0.0206 & 0.0196 & 0.0191 & $0.0930 * * *$ & $0.0650^{*}$ & $0.0570 *$ & $0.0561^{*}$ \\
\hline & $(0.0291)$ & $(0.0247)$ & $(0.0214)$ & $(0.0218)$ & $(0.0272)$ & $(0.0330)$ & $(0.0295)$ & $(0.0305)$ \\
\hline & [3.7633] & {$[0.8350]$} & {$[0.9168$} & [0.8768] & [3.4192] & [1.9661] & [1.9317] & [1.8399] \\
\hline \multirow{3}{*}{ TFPALTER $_{\mathrm{t}-2}$} & 1.4865 & 0.6558 & 0.0198 & 0.1680 & $-1.1052^{*}$ & $-1.071 * *$ & $-1.4105^{* *}$ & $-1.6000^{* *}$ \\
\hline & $(0.9318)$ & $(0.6914)$ & $(0.8001)$ & $(0.8976)$ & $(0.5751)$ & $(0.5337)$ & $(0.5501)$ & $(0.6793)$ \\
\hline & [1.5953] & {$[0.9484]$} & {$[0.0247]$} & [0.1872] & [-1.9217] & {$[-2.008]$} & {$[-2.5640]$} & {$[-2.3552]$} \\
\hline \multirow[t]{3}{*}{ DEV_IBC ${ }_{t-2}$} & 0.0132 & 0.0002 & -0.0040 & -0.0040 & & & & \\
\hline & $(0.0105)$ & $(0.0071)$ & $(0.0069)$ & $(0.0071)$ & & & & \\
\hline & [1.2537] & [0.0398] & {$[-0.5740]$} & {$[-0.5610]$} & & & & \\
\hline \multirow[t]{3}{*}{ DEV_U $\mathrm{t}_{\mathrm{t}-2}$} & & & & & $-0.1114 * * *$ & $-0.084 * *$ & $-0.0941^{* *}$ & $-0.0876^{* * *}$ \\
\hline & & & & & $(0.0339)$ & $(0.0369)$ & $(0.0393)$ & $(0.0400)$ \\
\hline & & & & & {$[-3.2856]$} & {$[-2.285]$} & {$[-2.3923]$} & {$[-2.1862]$} \\
\hline
\end{tabular}




\begin{tabular}{|c|c|c|c|c|c|c|c|c|}
\hline \multirow[t]{3}{*}{$\mathrm{EXCH}_{\mathrm{t}-2}$} & & & $1.8161 * *$ & $1.9937 * *$ & & & 1.4181 & 1.0070 \\
\hline & & & $(0.8820)$ & $(0.9819)$ & & & (0.8719) & $(0.8657)$ \\
\hline & & & [2.0590] & [2.0303] & & & [1.6263] & [1.1632] \\
\hline \multirow[t]{3}{*}{$\mathrm{D}(\mathrm{NFPS})_{\mathrm{t}-1}$} & & & & 0.0021 & & & & -0.0034 \\
\hline & & & & $(0.0059)$ & & & & $(0.0053)$ \\
\hline & & & & {$[0.3626]$} & & & & {$[-0.6498]$} \\
\hline Adjusted $\mathrm{R}^{2}$ & 0.0355 & 0.3359 & 0.3812 & 0.3584 & 0.2989 & 0.3847 & 0.3519 & 0.3760 \\
\hline J Statistic & 12.0558 & 8.1203 & 8.3302 & 8.3451 & 11.1927 & 12.1043 & 13.6049 & 13.2551 \\
\hline Prob (J) & 0.4412 & 0.7024 & 0.8214 & 0.7576 & 0.5124 & 0.3558 & 0.4022 & 0.3507 \\
\hline Instrument Rank & 16 & 16 & 19 & 19 & 16 & 16 & 19 & 19 \\
\hline
\end{tabular}

Obs.: () for standard deviation and [] for $\mathrm{t}$ statistic $(*)$ significant at $10 \%,(* *)$ at $5 \%$ and $(* * *)$ at $1 \%$.

Obs.: Instrumental variables used: EIPCA(t-2, t-3, t-4), SELIC(t-2, t-3, t-4), D(NFPS)(t-2, t-3, t-4), TFPBASE(t-3, t-4, t-5). The EXCH (t-3, $\mathrm{t}-4, \mathrm{t}-5), \mathrm{DEV} \_$IBC $(\mathrm{t}-3, \mathrm{t}-4, \mathrm{t}-5)$ and DEV_U(t-3, t-4, $\left.\mathrm{t}-5\right)$ instruments were used only when present in the regressions.

Source: Own elaboration.

The coefficient of the backward-looking inflation component was only partly significant in the estimations by GMM. Specifically, the lagged inflation coefficient was statistically significant (at 1\%) only in regressions with the output gap representing economic activity, with values between 0.6 and 0.71 . When the unemployment deviation was included in the estimations as a proxy for marginal cost, the backward-looking component lost statistical significance, despite the sign predicted by the theory.

Conversely, the expectation component was statistically significant when the unemployment gap was used as a representative of economic activity in the regressions. The values of the coefficients of inflation expectations were between 0.05 and 0.10 . With regard to the component that captures economic activity in the Phillips Curve, the deviation of unemployment had the best fit to the data, compared with the output gap. The deviation of $\mathrm{BC}-\mathrm{Br}$ index did not show statistical significance in any of the specifications, with the sign inverted in six of the twelve estimations tested. The coefficient of the unemployment rate deviation showed significance in all the regressions and with the negative sign predicted by the economic theory. The values of the unemployment rate deviation coefficients ranged between -0.07 and -0.12 .

Regarding the nominal exchange variation, it had statistical significance in seven of the twelve estimations, with the predicted positive sign in all cases. The values of the exchange variation coefficient varied from 1.45 to 2.00 , indicating a strong pass-through effect on the inflation of the period. In turn, the fiscal policy component was not significant in any of the estimation, with inverted signs in all cases.

The estimated regressions with the unemployment rate deviation (adjusted $\mathrm{R}^{2}$ between 0.28 and 0.39 ) had a better fit than the estimations with the output gap (adjusted $\mathrm{R}^{2}$ between 0.002 and 0.39). The use of the GMM allows a safer interpretation of the results due to the possible presence of endogeneity in the regressors (Note 8). The probability of the J Test was greater than 0.1 in all 24 specifications tested. Therefore, the null hypothesis of exogeneity of the instruments used was not rejected, pointing to a correct specification of the tested models.

\section{Concluding Remarks}

This work aimed to test an apparently intuitive hypothesis: that productivity growth can be transferred to prices and thus having a favorable impact on the inflation. To estimate the parameters of the proposed model, several regressions were performed using the Generalized Method of Moments (GMM). The coefficients associated with our TFP measures yielded the sign predicted by the theory and with statistical significance in 08 regressions. Thus, our GMM estimates point to some evidence of a negative relationship between TFP variation and inflation in Brazil, albeit in a way that is susceptible to the specifications of the models.

In turn, it was observed that the estimations made with the unemployment deviation had better accuracy, as well as results that confirmed the theoretical hypothesis of this work, compared with the estimates using the output deviation (by IBC-Br) as a proxy for the economic activity. All these results presented in this article have relevant implications for the monetary policy's strategy in the Brazilian economy. Specifically, policymakers should take into account productivity measures when calibrating decisions concerning basic interest rate adjustments, as the inflation rate periods ahead is sensible to the total factor productivity path over time.

Therefore, coordinated economic policies can contribute to enhance the credibility of the inflation targeting regime and the monetary policy's efficacy as long as the former supposedly affect productivity gains in Brazil over time. For instance, fiscal consolidation and a related decline of the public debt/GDP ratio would be a complimentary tool in this way, as it can allow for an improvement of investors and firms' confidence, a lower risk premium and an increase in investments, thereby stimulating positive shocks to PTF. In such a case, even when real GDP grows at 
higher rates, monetary policy is able to sustain a convergence of the expected inflation to its target at lower real interest rates, thus converging to some results in Snower and Tesfaselassie (2017).

\section{Acknowledgments}

We would like to thank CNPq (Brazil) for its financial support.

\section{References}

Ambrocio, G., \& Jang, T. (2009). Productivity shocks and the new Keynesian Phillips Curve: evidence from US and Euro Area. Kiel Advanced Studies Working Papers, 453, 1-15.

Areosa, W. D., \& Medeiros, M. (2007). Inflation dynamics in Brazil: the case of a small open economy. Brazilian Review of Econometrics, 27, 131-166. https://doi.org/10.12660/bre.v27n12007.1575

Ball, L., \& Moffitt, R. (2001). Productivity growth and the Phillips Curve. NBER Working Papers Series 8421, 1-50. https://doi.org/10.3386/w8421

Banco Central do Brasil. Sistema Gerenciador de Séries Temporais (SGS). Retrieved from https://www3.bcb.gov.br/sgspub

Barbosa Filho, F. H., \& Pessoa, S. A. (2014). Pessoal ocupado e jornada de trabalho: Uma releitura da evolução da

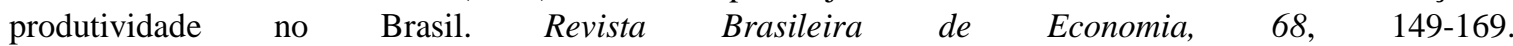
https://doi.org/10.1590/S0034-71402014000200001

Bonelli, R., \& Fonseca, R. (1998). Ganhos de produtividade e de eficiência: Novos resultados para a economia brasileira. Rio de Janeiro: IPEA, Textos para discussão, 557.

Clarida, R., Galí, J., \& Gertler, M. (1999). The science of monetary policy: A new keynesian perspective. Journal of Economic Literature, 37, 1661-1707. https://doi.org/10.1257/jel.37.4.1661

Cragg, J. G. (1983). More efficient estimation in the presence of heteroscedasticity of unknown form. Econometrica, 51, 751-763. https://doi.org/10.2307/1912156

Dew-Becker, I., \& Gordon, R. (2005). Where did the productivity growth go? Inflation dynamics and the distribution of income. NBER Working Papers Series, 11842, 1-86. https://doi.org/10.3386/w11842

Ellery, JR, R. (2014). Desafios para o cálculo da produtividade total dos fatores. In F. De Negri, \& L. R. Cavalcante (Eds.), Produtividade no Brasil. Desempenho e determinantes (pp. 53-86). Brasília: IPEA.

Ferreira, P. C., Ellery, JR, R., \& Gomes, V. (2008). Produtividade agregada brasileira (1970-2000): Declínio $\begin{array}{llllll}\text { robusto } \mathrm{e} \text { fraca } & \text { recuperação. }\end{array}$ https://doi.org/10.1590/S0101-41612008000100002

Ferreira, P. C., Pessoa, S. A., \& Veloso, F. (2013). On the evolution of total factor productivity in Latin America. Economic Inquiry, 51, 16-30. https://doi.org/10.1111/j.1465-7295.2011.00430.x

Galí, J., \& Gertler, M. (1999). Inflation dynamics: A structural econometric analysis. Journal of Monetary Economics, 44, 195-222. https://doi.org/10.1016/S0304-3932(99)00023-9

Galí, J., \& Monacelli, T. (2005). Monetary policy and exchange rate volatility in a small ppen economy. Review of Economic Studies, 72, 707-734. https://doi.org/10.1111/j.1467-937X.2005.00349.x

Gallegati, M., Gallegati, M., Ramsey, J. B., \& Semmler, W. (2016). Productivity and unemployment: a scale-by-scale panel data analysis for the G7 countries. Studies in Nonlinear Dynamics \& Econometrics, 20(4), 477-493. https://doi.org/10.1515/snde-2014-0053

Galvin, W. T., Keen, B. D., \& Pakko, M. R. (2012). Taylor-type rules and total factor productivity. Federal Reserve Bank of St. Louis Review, 94, 41-647. https://doi.org/10.20955/r.94.41-64

Gomes, V., Pessoa, S. A., \& Veloso, F. (2003). Evolução da produtividade total dos fatores na economia brasileira: uma análise comparativa. Pesquisa e Planejamento Econômico, 33, 389-434.

Hansen, L. P. (1982). Large sample properties of generalized method of moments estimators. Econometrica, 50, 1029-1054. https://doi.org/10.2307/1912775

Hulten, C. R. (2001). Total factor productivity: A short biography. In E. R. Dean, M. J. Harper \& C. R. Hulten (Eds.), New developments in productivity analysis (pp. 1-54). Chicago: University of Chicago Press. https://doi.org/10.7208/chicago/9780226360645.003.0001

Instituto Brasileiro de Geografia e Estatística - IBGE. Sistema IBGE de Recuperação Automática (SIDRA). Retrieved from https://sidra.ibge.gov.br/acervo\#/S 
Instituto de Pesquisa Econômica Aplicada - IPEA. (n. d.). IPEADATA. Retrieved from http://www.ipeadata.gov.br/Default.aspx

Johnston, J. (1984). Econometric Methods (3rd ed.). Singapore: McGraw-Hill Book Co.

Krugman, P. (1994). The age of diminished expectations: U.S. Economic Policy in the 1990s. Cambridge: MIT Press.

Mendonça, M. J. C., Sachsida, A., \& Medrano, C. R. (2012). Inflação versus desemprego: novas evidências para o Brasil. Economia Aplicada, 16, 475-500. https://doi.org/10.1590/S1413-80502012000300006

Mewael, F., \& Tesfaselassie, M. H. (2018). Wolters, The impact of growth on unemployment in a low vs. a high inflation environment, Review of Economic Dynamics, 28, 34-50. https://doi.org/10.1016/j.red.2017.07.005

Pesaran, M. H., \& Shin, Y. (1998). Generalized Impulse Response Analysis in Linear Multivariate Models. Economics Letters, 58, 17-29. https://doi.org/10.1016/S0165-1765(97)00214-0

Sachsida, A. (2013). Inflação, desemprego e choques cambiais: Uma revisão da literatura sobre a curva de Phillips no Brasil. Revista Brasileira de Economia, 67, 549-559. https://doi.org/10.1590/S0034-71402013000400009

Sachsida, A., Ribeiro, M., \& Dos Santos, C. H. (2009). Curva de Phillips e a experiência brasileira. Brasília: IPEA, 1429.

Schwartzman, F. (2006). Estimativa de Curva de Phillips para o Brasil com preços desagregados. Economia Aplicada, 10, 137-155. https://doi.org/10.1590/S1413-80502006000100008

Snower, D., \& Tesfaselassie, M. (2017). Job turnover, trend growth, and the long-run Phillips curve. Macroeconomic Dynamics, 21(4), 835-861. https://doi.org/10.1017/S136510051500070X

\section{Notes}

Note 1. www.ipeadata.gov.br

Note 2. The series available at IPEADATA indicates an average expectation for the next twelve months on the last working day of the month of reference.

Note 3. The unemployment series of the PNAD, with nationwide coverage, is calculated only from the first quarter of 2012. In turn, the use of the opened unemployment rate of São Paulo, calculated by the State Data Analysis System Foundation (SEADE), as a proxy for unemployment in Brazil, is supported by the literature on the subject. See Sachsida (2009).

Note 4. The regressions tested with the real exchange series had a bad fit. The sign of the coefficient of the variation of the actual exchange rate variation was the opposite of the theory's predictions, with no statistical significance in almost every estimation. Therefore, it was decided to adopt the series of the nominal exchange rate variation.

Note 5. The EAP series of the PNAD publishes only annual data. To complete the periods between the years, exponential interpolation was used.

Note 6 . The perpetual inventory method determines that: $K_{t+1}=(1-\delta) K_{t}+I_{t}$, where $K$ é the capital stock, $I$ is the investment and $\delta$ is the capital depreciation rate. For further details, see Gomes, Pessoa and Veloso (2003).

Note 7. Taken from the statistical annex of the article of Gomes, Pessoa and Veloso (2003), available at: <http://ppe.ipea.gov.br/x_anexos/ppe033301anexo.zip>. Accessed on 03 October 2015.

Note 8. Although it is not the purpose of this work to test this endogeneity itself, it is sufficient to consider that among the regressors used, such as economic activity, inflation expectations and exchange rate, there are strong theoretical elements that support this premise (Clarida, Gali, \& Gertler, 1999). In general, monetary policy affects, with time lags, all these regressors. This is why the Selic rate was also used as an instrumental variable.

\section{Copyrights}

Copyright for this article is retained by the author(s), with first publication rights granted to the journal.

This is an open-access article distributed under the terms and conditions of the Creative Commons Attribution license (http://creativecommons.org/licenses/by/4.0/). 